\title{
Gifted education: Perspectives and practices of school principals in Bahrain
}

\author{
Osama Al-Mahdi, Abduyah Binte Yaakub, Abdelbaky Abouzeid \\ Educational Studies Department, Bahrain Teachers College, University of Bahrain, Bahrain
}

\begin{tabular}{l} 
Article Info \\
\hline Article history: \\
Received Nov 3, 2020 \\
Revised Mar 9, 2021 \\
Accepted Apr 12, 2021 \\
\hline
\end{tabular}

\section{Keywords:}

Giftedness

Perceptions

School leadership

School perspective

Talents and creativity

\begin{abstract}
Research on giftedness and gifted education has a rich history. Researchers have consistently pointed to the educational leadership perspectives on giftedness, and inequitable identification of policies and practices in gifted education. Research suggests there is a widening gap in the level of comprehensive knowledge in gifted education that is critical for school improvement. This paper examined school principals' $(n=29)$ perceptions regarding giftedness among Bahraini students. The study focuses on exploring the characteristics school principals attribute to giftedness in their schools, the methods employed by schools to identify gifted students from the school principals' perspectives, and the educational provisions school principals used to support gifted students in their school. The study also searches for any significant differences among school principals in their views on these three dimensions. The study employed quantitative methodology and the analysis of the research questionnaire included descriptive and interpretive analysis (ANOVA and T-test). The findings indicate that the school principals looked at giftedness mainly from an academic and school perspective. The results indicate some dissonance between what the principals' perceptions on giftedness are and the educational support that they provided to the gifted students in their schools.
\end{abstract}

This is an open access article under the CC BY-SA license.

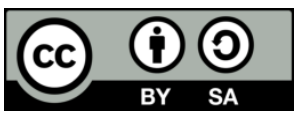

\section{Corresponding Author:}

Osama Al-Mahdi

Educational Studies Department, Bahrain Teachers College

University of Bahrain

Bahrain International Circuit, Zallaq, Bahrain

Email: oalmahdi@uob.edu.bh

\section{INTRODUCTION}

This study aimed to investigate the perceptions of a sample of Bahraini school principals on the characteristics of gifted students, and ways for identifying those students, and provisions to meet their educational needs. The reason for focusing on this particular research area is that there is currently a growing interest in facilitating gifted students' learning as an essential at the least, in any world class educational system, gifted education can never be disregarded [1]. There is a need for in-depth study about provisions for fulfilling the needs effectively through understanding characteristics, ways for identifying giftedness, and educational practices emplaced [2]. This study examines those dimensions. Gifted students need special support and social, psychological and emotional guidance [3], [4]. Such high aspirations are possible when we understand their special needs [5].

Smedsrud [6] argued that it is difficult to have one conclusive definition on the concept of giftedness due to different perspectives. Psychometric approach mainly use where students achieving high scores in intelligence tests are identified gifted students. Then, the cognitive approach came and used two tools in the 
identification process: intelligent tests and standardized academic tests in specific school subjects. After which, creative approach used three tools: intelligent tests, standardized test, and other creative tools such as portfolios, interviews, and individual strength points in the gifted student. Smedsrud [6] contended that the traditional approach of identifying gifted students that is based on intelligent tests and academic achievement can have weakness as it may focuses more on specific mental abilities such as memorization or reasoning and pay less attention to other mental and cultural aspects like creativity which can play a key role in the identification process.

Sternberg [7] introduced the educational approach, which emphasized the idea of successful intelligence in cultural aspects of giftedness and on understanding how family, school and the social context can influence giftedness, and not just relying on intelligence and academic testing. In addition, Renzulli [8] discussed the three dimensions of giftedness: above average abilities, creativity, and persistency. Gagnes [9] offered a framework that distinguished between two ideas: creativity linked with aptitude in comparison to talent linked with performance. Heller, et al. [10] and Monks [11] argued that giftedness is an outcome of a process of the interaction of various biological and environmental factors and therefore it is important to learn more about the role of the social context, which includes the student's family, peers, and school. Vinner and Pont [12] as well as David [13] stated that the school principal's leadership qualities including setting difficult goals has great influence in determining the school culture and the whole school community towards appreciating giftedness. It is also important to understand the nature of psychological makeup of the individual in terms of his or her motivation and self-efficacy [14]. Matthews and Dai [15] highlighted the growth of research that emphasized that giftedness is a dynamic process produced through the interaction between various factors, dispositions, aptitudes, cultural and social environment that surround the individual and not a process, merely grounded on academic achievement or intelligent quotient (IQ). Therefore, it is important to researchers who are studying giftedness to learn more about the perceptions of people who are dealing with gifted students on daily bases such as parents, teachers and school leaders in order to understand the social and cultural contexts.

The current study adopts the following definition of giftedness offered by Cross and Coleman [16, p. 96], "Giftedness is an age-specific term that refers to the potential of young persons who are judged to have demonstrated rapid learning compared with their peers. The judgement is made on the basis of some normative standard ... creativity is a term that denotes the production of an original idea or behavior that changes the way others think about or behave in an area of worthwhile human endeavor. The standards for judging creativity extend from the personal to the societal." Many educators [17]-[19] had grown weary of conceptualizations that described constructs, including giftedness, as just being either cognitive or environmental. Vinne and Port [12] contended that the school psychologist is an important stakeholder in the education system thus they should have familiarity with gifted education policy to ensure that students are being served appropriately-both academically and socio-emotionally. This brings us to another environmental aspect to look into deeper as educational scholars like Plucker and Callahan [5] who offer an integrated model of giftedness in which talents, broadly defined, are developed through the interaction of individual, environment, and the social-cultural dimension. These three theoretical approaches also emphasized the role of socio-cultural context [20] in defining, identifying, and fostering giftedness, which clearly framed this study. Although, there was a research done in Bahrain [21], the study focused on the differences in the emotional intelligence (EQ) of gifted and talented adolescent students the study indicated that there were significant differences in EQ in favor of the gifted students to the talented ones. This study also highlighted that the gifted males are higher in EQ compared to the gifted females, while the talented females scored higher than the talented males in interpersonal scores.

Nevertheless, identifying and nurturing gifted and talented students is urgently needed in the gulf cooperation council (GCC) countries, particularly in Bahrain - where the paper authors currently work and conducted their research - in order to keep up with demands of the 21st centuries needs and challenges of the nation is very important. A new philosophical perspective has begun to influence views of learning, giftedness and talent. This study hopes to contribute to the educational efforts in providing better learning opportunities for gifted students in Bahrain.

\section{LITERATURE REVIEW}

David [13] presented in her chapter book rationalized on which the identification of giftedness and the suggested programs for giftedness are central to the benefit of gifted children and youths in the Middle East. Chan [22] on the other hand argued that despite the amazing diversity, when the development of gifted education is considered in the world, countries like Singapore, Japan, South Korea and China in Asia are also focusing on how the identification of the giftedness and the gifted education programs and practices as the leading momentum towards progress, development and innovation. Pursuing excellence is emphasized in the 
educational policy discourses to appropriately support the development of every student's academic capabilities. For example, in the United States, NAGC [23, p.1] defined excellence as “... the need of every learner to have opportunities and adult support necessary to maximize his or her learning potential."

Endepohls-Ulpe and Ruf [24] investigated the standards for identifying gifted students used by primary teachers in Germany. The study sample included 384 male and female teachers. Interviews and questionnaires were used in the data collection. Finding of the study indicated that most of the teachers considered high cognitive abilities as the main criterion of giftedness with some of the teachers indicated that motivation also play key role in this process. Most of the teachers showed positive attitudes toward dealing with gifted students and they indicated that characteristics of giftedness vary between primary and secondary school levels.

Moon and Brighton [25] gave an overview on the results of a research project that conducted by the National Research Centre for Giftedness and Talented in the United State. The study sample included 434 teachers and used questionnaire and case studies to investigate primary school teachers' perceptions and practices with regard to gifted students. Findings of the study indicated that most of the teachers held traditional perceptions about giftedness such as excellence in academic skills such as reading and writing, language proficiency, and general knowledge. Less attention given to identifying gifted students who come from social and ethnic minorities, or low-income families, or non-native English speakers. These social and cultural factors acted as a barrier to investing the students' giftedness.

Laine, et al. [26] explored primary and secondary school teachers' perceptions about giftedness in Finland in two research projects. The first project included 212 primary teachers and the second included 279 secondary school teachers. The study used questionnaires and content analysis methods. Findings of the studies indicated that the teachers had a multidimensional perspective on giftedness in which it includes cogitative and creative dimensions. In addition, the teachers indicated that motivation and growth mindset play key role in nurturing giftedness. Teachers tend to compare among students and perceive giftedness as not static and can change during the individual's life. The study concluded that there is a need for more training and preparation for teachers in the area of identifying and dealing with gifted students.

Finley's [4] research focused on the identification process for gifted students. Finley described the promotion of a separate, elitist attitude among the gifted population and the lack of connectedness to or extension of the general curriculum to the seminar curriculum. Sternberg and Davidson [27, p. 36] propose for a seminar curriculum for the gifted: "an advance curriculum matches gifted abilities and incorporates the opportunity to explore topics in depth while surrounded by academic peers." Every gifted child deserves to be engaged in meaningful and powerful learning at his or her most appropriate points that stretched and challenged their readiness, interest, and learning profile to achieve their fullest potential. Seminar curriculum developed in order to provide enriched curriculum for the identified gifted students and to address their need for the development of higher-level thinking, problem solving, and research skills. Finley [4] observed that this differentiated instruction model in some schools in US provide opportunity for gifted students (2-hours per week) to interact with their intellectual peers in collaborative groups as they participate in enriching and challenging projects. Finley also offered implications for practice, namely to undergo a critical review of the school's program, update and align curriculum with research, address concerns about the identification process that mandates very superior IQ scores of 130, attend to the diversity within giftedness, and more.

Quek, et al. [28] in their study to explore effective practices in teaching and learning environment emphasised the need for teacher-student interaction that could help the gifted to learn better. The research also imply the importance of customizing instructions, and infusing creative and critical thinking skills. The researchers recommended for an appropriate curriculum revised taking into account the intellectually stimulating environment and the dynamics of the communication process. The study showed that the interpersonal behaviour of teachers have an impact on the students. In order to encourage positive results, teachers could incorporate more real-life investigative work. This signal that in order for any gifted education to thrive, positive relationship between students, teachers and the school leaders need to be established.

DiPaola and Walter-Thomas [29] study indicated the role of the principal shifted to that of the instructional leader in the 1980s and more recently as learning leader. They now play the role as an agent of change in the teaching, learning, and implementation process [30]. Hess and Kelly [31], [32] studies on principal preparation program in US implied that because the "preparation of principals has not kept pace with changes in the larger world of schooling, graduates of leadership-preparation programs have been left ill-equipped for the challenges and opportunities posed by an era of accountability" (p. 40). The lack of gifted education content may lead principals to begin their careers without the ability to oversee effectively concerns related to gifted students.

Hence, the rationale for the current study emerged from a desire to uncover what we currently know, what we do not know, and what we still need to know about leadership perception of giftedness in Bahrain schools. We hope to enable a systemic reform, and create policies that fosters optimal growth of appropriate 
gifted educational programs. There is insufficient research that examines the extent of gifted education practiced in Bahraini school. This study bring some light to examining and understanding the local context. The topics in the survey correspond with what the literature indicates principals should know about exceptional and gifted student education.

\section{RESEARCH METHOD}

This study employed quantitative descriptive methodology to investigate school principals' perceptions of giftedness among students in Bahraini schools. Data was collected through a questionnaire designed in Likert Scale format that was originally developed by Nagara [33] and translated to Arabic and used with a Bahraini Teachers' sample $(n=80)$ with a split-half reliability coefficient of 0.74 [34]. We use the same questionnaire again in this study to investigate Bahraini school principals' perceptions in three sections: 1) Characteristics school principals attribute to giftedness in students; 2) Methods employed by schools to identify students presumed to be gifted in their schools; and 3) Educational provisions school principals adopted to include gifted students in their school. The questionnaire had five Likert Scale type options that were coded in SPSS analysis (Strongly Agree=5, Agree=4, Neutral=3, Disagree=2, and Strongly Disagree=1). The questionnaire was administered by the first author to a group of consenting school principals. Participation in the study was voluntary. Various statistical descriptive data analysis techniques were used such as measures of central tendency and inferential statistic such as t-test and One-way Analysis of Variance (ANOVA) to determine if there are significant differences between the means of two groups or to compare means of two or more samples. The value of the split-half reliability coefficient of the questionnaire in the current study is 0.79 .

\subsection{Sample}

The sample of this study consisted of 29 school principals (15 females, 14 males). Although the sample size is relatively small but they represent $7 \%$ of the research population (the total number of public schools in Bahrain is 209). Availability sampling is used in this study. The researchers reached more than 100 school principals who were accessible at that time and received completed surveys from only 29 of them. The participants' work experience varied from (6 to 21) years. Thirteen participants have (11 to 15) years of work experience while 11 of them had 21 years of experience or more. In addition, high number of the participants (18) work in intermediate schools while lower numbers work in primary or secondary schools. All of the participants hold a Bachelor degree and three of them hold higher degrees such as PhD or Masters as shown in Table 1 to Table 4.

Table 1. School principals sample distribution

\begin{tabular}{ccc}
\multicolumn{3}{c}{ according to the gender variable } \\
\hline Gender & Frequency & Percentage \\
\hline Male & 14 & 48.3 \\
Female & 15 & 51.7 \\
Total & 29 & 100 \\
\hline
\end{tabular}

Table 3. School principals sample distribution

\begin{tabular}{ccc}
\multicolumn{3}{c}{ according to the school level variable } \\
\hline School level & Frequency & Percentage \\
\hline Primary cycle 1 & 6 & 20.7 \\
Intermediate & 18 & 62.1 \\
Secondary & 5 & 17.2 \\
Total & 29 & 100 \\
\hline
\end{tabular}

Table 2. School principals sample distribution according to the work experience variable

\begin{tabular}{ccc}
\hline Work experience & Frequency & Percentage \\
\hline 6 to 10 & 3 & 10.3 \\
11 to 15 & 13 & 44.8 \\
16 to 20 & 2 & 6.9 \\
21 and more & 11 & 37.9 \\
Total & 29 & 100 \\
\hline
\end{tabular}

Table 4. School principals sample distribution according to the qualification variable

\begin{tabular}{ccc}
\hline Qualification & Frequency & Percentage \\
\hline Bachelor & 26 & 89.7 \\
Postgraduate & 3 & 10.3 \\
Total & 29 & 100
\end{tabular}

\section{RESULTS}

To answer the first research question: What are the characteristics school principals attribute to giftedness in students in their schools? The researcher calculated frequencies, percentages, averages, and standard deviations for the participants' responses in the questionnaire. The results shown in Table 5 indicate that the general average of the characteristics school principals attribute to giftedness in students in their schools is (3.84) with a percentage of $(76.90 \%)$. The school principals indicated that the most important characteristic of gifted students is (They show intense interest in some subjects). The mean for this item was (4.45) with a percentage of $(88.97 \%)$. The second most important characteristic is (are born with the 
inherent/innate gifts, do not need to put effort). The mean for this item was (4.07) with a percentage of $(81.38 \%)$. The school principals indicated that the lowest characteristic of giftedness is (Excel in both academic and non-academic areas) with an average of (3.59) and percentage of (71.72\%). The second lowest characteristic was (Have natural exceptional abilities) with an average of (3.62) and percentage of (72.41\%).

Table 5. Frequencies, percentages, averages, and standard deviations of school principals' perceptions on the

\begin{tabular}{|c|c|c|c|c|c|c|c|c|c|c|c|c|c|}
\hline \multirow{2}{*}{$\begin{array}{c}\text { Characteristics of gifted } \\
\text { students }\end{array}$} & \multicolumn{2}{|c|}{ S. Agree } & \multicolumn{2}{|c|}{ Agree } & \multicolumn{2}{|c|}{ Neutral } & \multicolumn{2}{|c|}{ Disagree } & \multicolumn{2}{|c|}{ S.Disagree } & \multirow[b]{2}{*}{ Mean } & \multirow[b]{2}{*}{$\mathrm{SD}$} & \multirow[b]{2}{*}{$\%$} \\
\hline & Freq & $\%$ & Freq & $\%$ & Freq & $\%$ & Freq & $\%$ & Freq & $\%$ & & & \\
\hline $\begin{array}{l}\text { Show intense interest in some } \\
\text { subjects }\end{array}$ & 13 & 44.8 & 16 & 55.2 & - & - & - & - & - & - & 4.45 & 0.51 & 88.97 \\
\hline $\begin{array}{l}\text { Are born with the inherent/ } \\
\text { innate gifts, do not need to } \\
\text { put effort }\end{array}$ & 12 & 41.4 & 11 & 37.9 & 2 & 6.9 & 4 & 13.8 & - & - & 4.07 & 1.03 & 81.38 \\
\hline $\begin{array}{l}\text { Are quick to grasp concepts/ } \\
\text { finish class assignments }\end{array}$ & 11 & 37.9 & 10 & 34.5 & 4 & 13.8 & 4 & 13.8 & - & - & 3.97 & 1.05 & 79.31 \\
\hline $\begin{array}{l}\text { Excel in non-academic areas } \\
\text { such as sports, drama, art, } \\
\text { music }\end{array}$ & 13 & 44.8 & 5 & 17.2 & 6 & 20.7 & 5 & 17.2 & - & - & 3.90 & 1.18 & 77.93 \\
\hline $\begin{array}{l}\text { Show good memory of what } \\
\text { they learn }\end{array}$ & 7 & 24.1 & 13 & 44.8 & 4 & 13.8 & 5 & 17.2 & - & - & 3.76 & 1.02 & 75.17 \\
\hline $\begin{array}{l}\text { Excel in academic/intellectual } \\
\text { subjects (math, languages, } \\
\text { science and other subjects) }\end{array}$ & 5 & 17.2 & 17 & 58.6 & 1 & 3.4 & 6 & 20.7 & - & - & 3.72 & 1.00 & 74.48 \\
\hline $\begin{array}{l}\text { Always score high in tests } \\
\text { and examination }\end{array}$ & 7 & 24.1 & 13 & 44.8 & 3 & 10.3 & 5 & 17.2 & 1 & 3.4 & 3.69 & 1.14 & 73.79 \\
\hline $\begin{array}{l}\text { Do not need to work hard, can } \\
\text { easily sail through with little } \\
\text { effort }\end{array}$ & 7 & 24.1 & 12 & 41.4 & 4 & 13.8 & 6 & 20.7 & - & - & 3.69 & 1.07 & 73.79 \\
\hline $\begin{array}{l}\text { Have natural exceptional } \\
\text { abilities }\end{array}$ & 7 & 24.1 & 11 & 37.9 & 4 & 13.8 & 7 & 24.1 & - & - & 3.62 & 1.12 & 72.41 \\
\hline $\begin{array}{l}\text { Excel in both academic and } \\
\text { non-academic areas }\end{array}$ & 8 & 27.6 & 8 & 27.6 & 6 & 20.7 & 7 & 24.1 & - & - & 3.59 & 1.15 & 71.72 \\
\hline Total & & & & & & & & & & & 3.84 & 1.03 & 76.90 \\
\hline
\end{tabular}

To answer the second research question: Are there any significant differences among school principals in their views on the characteristics of gifted students that attributed to the following variables: gender, work experience, subject, school level, and qualification? The researchers calculated t-test and ANOVA values to find any significant differences as shown in Table 6 to Table 9.

Findings of t-test indicated that there were no statistically significant differences $(0.744>.05)$ found between school principals' in terms of their views on the characteristics of gifted students that can be attributed to the gender variable. Findings from ANOVA analysis indicated that there were no statistically significant differences between the school principals with a significance level of $(0.319>.05)$ attributed to the work experience variable for this dimension in general. However, using ANOVA analysis on the individual items indicated that there is significant difference between the school principals in the item (show good memory of what they learn) with a significance level $(.046<.05)$ as shown in Table 6.

Table 6. ANOVA results-differences in school principals' perceptions towards giftedness according to the work experience variable

\begin{tabular}{ccccccc}
\hline & & Sum of squares & df & Mean square & F & Sig. \\
\hline \multirow{2}{*}{ Show good memory of what } & Between groups & 7.906 & 3 & 2.635 & 3.078 & .046 \\
they learn & Within groups & 21.404 & 25 & .856 & & \\
& Total & 29.310 & 28 & & & \\
\hline
\end{tabular}

The least significance difference (LSD) test was used to know the direction of these differences to which level of school principals' work experience. The findings indicate that the difference is in favor of the following work experience years: (6-10) and (11-15 years) with significant levels of (.040), (.027) and $(.047)<.05$ as shows in Table 7.

Findings from ANOVA analysis indicated that there were no statistically significant differences between the school principals with a significance level of $(0.095>.05)$ attributed to the school level variable 
for this dimension in general. However, using ANOVA analysis on the individual items indicated that there is significant difference between the school principals in the item (show good memory of what they learn) with a significance level $(.042<.05)$ and in the item (Excel in both academic and non-academic areas) with a significance level $(.007<.05)$ as shown in Table 8.

The least significance difference (LSD) test was again used to know the direction of these differences to which school level. The findings indicated that this difference is in favor to the intermediate school level with significant levels of (.002) and (.019)<.05 as shown in Table 9.

Table 7. LSD post-test: Direction of differences in school principals' perceptions towards giftedness according to the work experience variable

\begin{tabular}{cccccc}
\hline Dependent variable & $(\mathrm{I}) \exp$ & $(\mathrm{J})$ exp & Mean difference (I-J) & Std. error & Sig. \\
\hline \multirow{3}{*}{ Show good memory of what they learn } & 6 to 10 & 16 to 20 & $1.83333^{*}$ & .84468 & .040 \\
& 11 to 15 & 16 to 20 & $1.65385^{*}$ & .70281 & .027 \\
& & 21 and more & $.79021^{*}$ & .37907 & .047 \\
\hline
\end{tabular}

Table 8. ANOVA results-differences in school principals' perceptions towards giftedness according to the school level variable

\begin{tabular}{|c|c|c|c|c|c|c|}
\hline Dependent variable & & Sum of squares & $\mathrm{df}$ & Mean square & $\mathrm{F}$ & Sig. \\
\hline \multirow{3}{*}{ Show good memory of what they learn } & Between groups & 11.790 & 2 & 5.895 & 6.071 & .007 \\
\hline & Within groups & 25.244 & 26 & .971 & & \\
\hline & Total & 37.034 & 28 & & & \\
\hline \multirow{3}{*}{ Excel in both academic and non-academic areas } & Between groups & 6.333 & 2 & 3.166 & 3.583 & .042 \\
\hline & Within groups & 22.978 & 26 & .884 & & \\
\hline & Total & 29.310 & 28 & & & \\
\hline
\end{tabular}

Table 9. LSD post-test: Direction of differences in school principals' perceptions towards giftedness according to the school level variable

\begin{tabular}{|c|c|c|c|c|c|}
\hline Dependent variable & (I) Cycle & (J) Cycle & Mean difference (I-J) & Std. error & Sig. \\
\hline Excel in both academic and non-academic areas & Primary cycle 1 & Intermediate & $-1.55556^{*}$ & .46450 & .002 \\
\hline Show good memory of what they learn & Primary cycle 1 & Intermediate & $-1.11111 *$ & .44316 & .019 \\
\hline
\end{tabular}

Finally, findings from ANOVA analysis indicated that there were no statistically significant differences between the school principals with a significance level of (0.096>.05) attributed to the qualification variable for this dimension in general.

To answer the third research question: What methods employed by schools to identify presumably gifted students from the school principals' perspectives? The researcher calculated frequencies, percentages, averages, and standard deviations for the participants responses in the questionnaire as shown in Table 10 which indicated that the most used identification method is (Checklists of gifted characteristics of giftedness) with an average of (4.45) and percentage of (88.97\%). The second most used method was (a combination of methods/multiple dimensional methods) with an average of (4.31) and percentage of $(86.21 \%)$. The least used identification method was (Peer nomination-informed by other students) with an average of (3.93) and percentage $(78.62 \%)$ and, (Parents nomination-informed by parents) with an average of (3.97) and percentage $(79.31 \%)$

To answer the fourth research question: Are there significant differences among school principals in their views on the identification methods of gifted students that attributed to these variables: gender, work experience, subject, school level, and qualification? The researchers calculated t-test and ANOVA values to find any significant differences. The t-test results indicated no significant differences found between school principals in terms of their views on the identification methods of gifted students that can be attributed to the gender variable (significance level 0.084>.05), the work experience variable (significance level 0.637>.05), the school level variable (significance level 0.670>.05), and qualification variable (significance level $0.10>.05)$. 
Table 10. Frequencies, percentages, averages, and standard deviations of school principals' perceptions on method of identifying gifted students

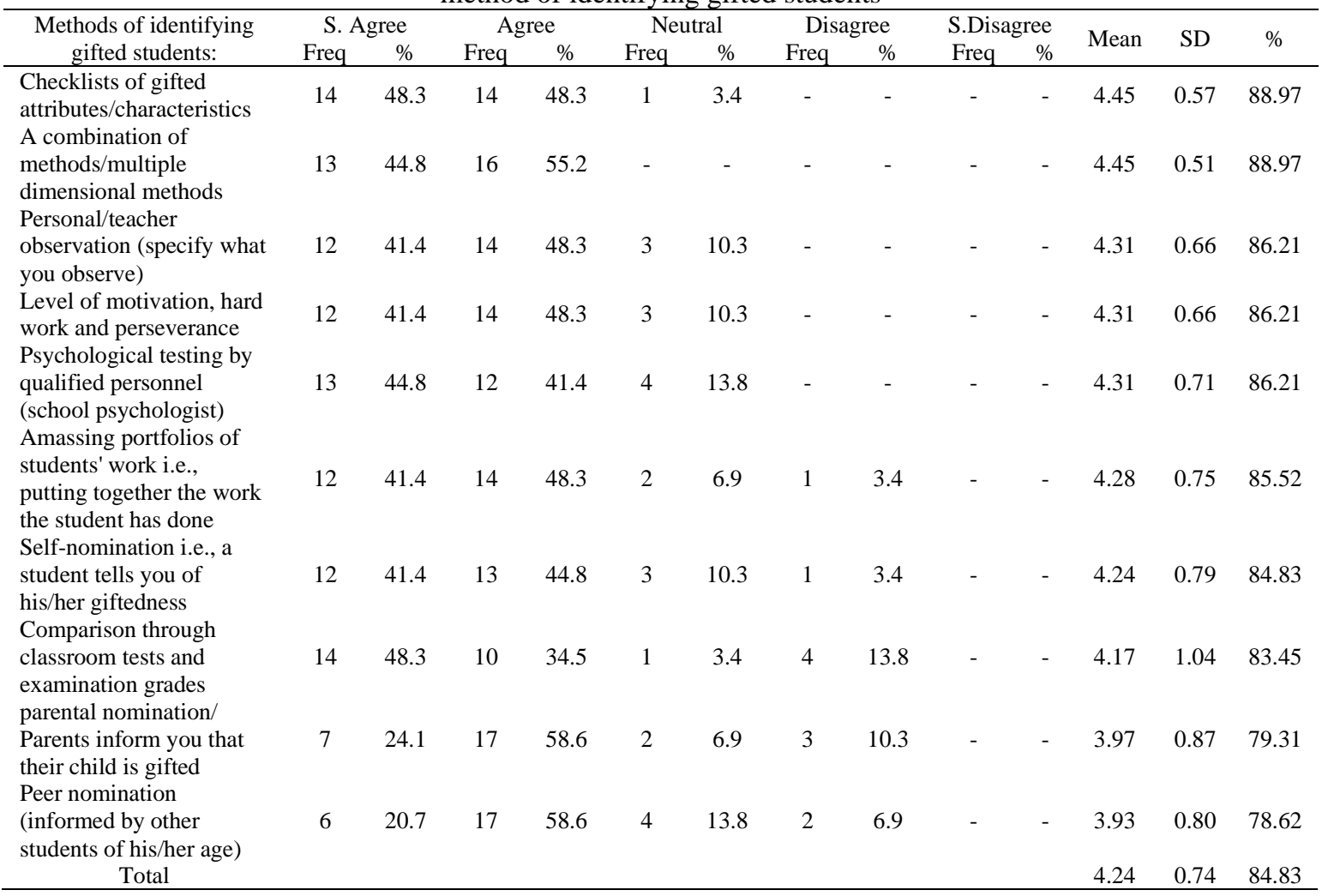

To answer the fifth research question: What are the educational provisions school principals used to support gifted students in their school? The researcher calculated frequencies, percentages, averages, and standard deviations for the participants responses in the questionnaire as shown in Table 11 which indicated the general average of the participants' perceptions on the educational provisions used to support gifted students was (4.32) with a percentage of $(86.33 \%)$. The most used educational provisions were (Through ability grouping) with an average (4.72) and percentage (94.48\%). The second type of provisions used in the schools was (Through research projects in their areas of strength) with an average (4.59) and percentage $(91.72 \%)$. The least type of provisions used in schools was (through acceleration through grade skipping) with an average (3.38) and percentage (67.59\%) and (by acceleration programs) with an average (3.86) and percentage $(77.24 \%)$.

To answer the sixth research questions: Are there significant differences among school principals in their views on the provisions offered to support gifted students that can be attributed to the following variables: gender, work experience, school level, and qualification? The researchers calculated t-test and ANOVA values to find if there are any significant differences. Findings of t-test indicated that there were no statistically significant differences $(0.736>.05)$ found between school principals in terms of their views on the provisions offered to support gifted students that can be attributed to the gender variable. Similarly, no statistically significant differences $(0.652>.05)$ were found that can be attributed to the work experience variable on the general dimension. Also, no statistically significant differences $(0.484>.05)$ were found that can be attributed to the school level variable on the general dimension. The only significant difference between school principals' perceptions on the provisions offered to gifted students $(0.040<.05)$ was attributed to the qualification variable. It was not possible to figure those differences are in favor of which qualification level because there was only three principals in the sample with postgraduate degrees (Table 12).

It is interesting to note that there is a lack of statistical significance found in the variables for gender, subject and qualification of the school principal. Nevertheless, in the areas of work experience and school level of the school principal showed statistically significant in favor of the intermediate school level where the dependent variables such as showing good memory and excel both in academic and non-academic subjects are concerned. 
Table 11. Frequencies, percentages, averages, and standard deviations of school principals' perceptions on educational provisions used to support gifted students

\begin{tabular}{|c|c|c|c|c|c|c|c|c|c|c|c|c|c|}
\hline \multirow{2}{*}{$\begin{array}{c}\text { Educational provisions } \\
\text { used }\end{array}$} & \multicolumn{2}{|c|}{ S. Agree } & \multicolumn{2}{|c|}{ Agree } & \multicolumn{2}{|c|}{ Neutral } & \multicolumn{2}{|c|}{ Disagree } & \multicolumn{2}{|c|}{ S.Disagree } & \multirow{2}{*}{ Mean } & \multirow{2}{*}{ SD } & \multirow{2}{*}{$\%$} \\
\hline & Freq & $\%$ & Freq & $\%$ & Freq & $\%$ & Freq & $\%$ & Freq & $\%$ & & & \\
\hline $\begin{array}{l}\text { Grouping students } \\
\text { according to their gifted } \\
\text { abilities }\end{array}$ & 21 & 72.4 & 8 & 27.6 & - & - & - & - & - & - & 4.72 & 0.45 & 94.48 \\
\hline $\begin{array}{l}\text { Doing projects in students' } \\
\text { areas of strengths and } \\
\text { interests }\end{array}$ & 17 & 58.6 & 12 & 41.4 & - & - & - & - & - & - & 4.59 & 0.50 & 91.72 \\
\hline $\begin{array}{l}\text { Through enrichment } \\
\text { programs that broadly } \\
\text { develop students' horizons } \\
\text { and interests }\end{array}$ & 17 & 58.6 & 12 & 41.4 & - & - & - & - & - & - & 4.59 & 0.50 & 91.72 \\
\hline $\begin{array}{l}\text { Special out of school } \\
\text { weekend/summer/vacation } \\
\text { programs for gifted } \\
\text { students }\end{array}$ & 17 & 58.6 & 11 & 37.9 & 1 & 3.4 & - & - & - & - & 4.55 & 0.57 & 91.03 \\
\hline $\begin{array}{l}\text { Differentiated programs } \\
\text { using group work }\end{array}$ & 14 & 48.3 & 14 & 48.3 & 1 & 3.4 & - & - & - & - & 4.45 & 0.57 & 88.97 \\
\hline $\begin{array}{l}\text { Providing challenging } \\
\text { learning tasks }\end{array}$ & 13 & 44.8 & 16 & 55.2 & - & - & - & - & - & - & 4.45 & 0.51 & 88.97 \\
\hline $\begin{array}{l}\text { By giving students extra or } \\
\text { more work to occupy them }\end{array}$ & 12 & 41.4 & 16 & 55.2 & - & - & 1 & 3.4 & - & - & 4.34 & 0.67 & 86.90 \\
\hline $\begin{array}{l}\text { Engaging students in } \\
\text { solving social problems }\end{array}$ & 12 & 41.4 & 15 & 51.7 & 2 & 6.9 & - & - & - & - & 4.34 & 0.61 & 86.90 \\
\hline $\begin{array}{l}\text { Special class in selected } \\
\text { subjects such as science, } \\
\text { math and art and regular } \\
\text { class for all other learning }\end{array}$ & 10 & 34.5 & 16 & 55.2 & 2 & 6.9 & 1 & 3.4 & - & - & 4.21 & 0.73 & 84.14 \\
\hline By acceleration programs & 6 & 20.7 & 15 & 51.7 & 6 & 20.7 & 2 & 6.9 & - & - & 3.86 & 0.83 & 77.24 \\
\hline $\begin{array}{l}\text { By acceleration through } \\
\text { grade skipping }\end{array}$ & 3 & 10.3 & 12 & 41.4 & 7 & 24.1 & 7 & 24 & - & - & 3.38 & 0.98 & 67.59 \\
\hline Total & & & & & & & & & & & 4.32 & 0.63 & 86.33 \\
\hline
\end{tabular}

Table 12. ANOVA results-differences in school principals' perceptions on the provisions offered to support gifted students (for the whole dimension) according to the qualification variable

\begin{tabular}{ccccccc}
\hline & Sum of squares & $\mathrm{df}$ & Mean square & $\mathrm{F}$ & Sig. \\
\hline Dimension 3 & Between groups & .556 & 1 & .556 & 4.655 & .040 \\
& Within groups & 3.223 & 27 & .119 & & \\
& Total & 3.779 & 28 & & & \\
\hline
\end{tabular}

\section{DISCUSSION}

First, it is important to highlight that the number of participants in this study is quite small, therefore it is difficult to say that these perceptions would reflect the wider population of school principals in Bahrain. There are in total 209 public schools in Bahrain. The current sample of 29 participants represent $14 \%$ of the study population including male and female school principals with a vast and variety of experiences teaching and managing different levels of schools. They are also qualified in their subject specialization and in educational and leadership knowledge and skills.

We noticed in the results of the first question that the school principals gave higher ranking to the following characteristics of giftedness: show intense interest in some subjects, are born with the inherent/innate gifts, do not need to put effort, are quick to grasp concepts/finish class assignments, and excel in non-academic areas such as sports, drama, art, music. The school principal perspectives in this study were congruent with the study [21] in Bahrain where the concept of giftedness differs to talent. This indicates that they look at giftedness from an academic and school perspective as highlighted by Smedsrud [6]. It is interesting to note that the Bahraini principals' perceptions of giftedness correlate with some of the characteristics of giftedness observed by Sternberg and Davidson [27] and also research conducted more recently [14], in having similar pathways of identification which also indicated more emphasis on academic aspects.

The results of the second question generally indicate the sample homogeneity, as there were almost no significant differences among the participants surveyed. Their similar training and professional development explain the homogeneity among the schools principals' perspectives about what giftedness could possibly entails. Given Bahrain centralized education system, such the standardized practice of recruiting and promoting school leaders are somehow constant across all levels. While the results indicate 
homogeneity in general, it is interesting to note that there were only two significant differences in the school principals' perceptions towards giftedness in terms of excelling in both academic and non-academic areas. Another dimension is showing good memory of what they learn. This significant result could probably because some school principals may not consider these two dimensions as methods to identify giftedness in the students. Quek, et al. [28] and Heuser, et al. [35] argued there are different constructs of talents, intelligence and ability when comparing the perception, policies, and practices across different norms of established systems. Stephens [36] highlighted the importance of policies in establishing sound transition from policy to implementation in order for gifted education program to be impactful across many levels. It can either hinder or support the transition from policy to practice.

The results of the third question indicate that the school principals gave higher ranking to the following methods of identifying gifted students: Checklists of gifted attributes/characteristics, a combination of methods, multiple dimensional methods and personal and teacher observation. Still it seems that they perceive giftedness as abilities related to school and academic work. They did not give high attention to parental or peer opinions. There is a dissonance in this area as Khalifa [37] has emphasized that parental involvement is pivotal to ensure progressive development and success in any gifted education program.

The results of the fourth question generally indicate the homogeneity of the sample, as there were almost no significant differences among them in their perspectives on methods of identifying gifted students. The literature indicates strong influence in terms of expanding notions like multiple intelligences (MI) championed by Gardner [38]. Despite the MI's theory's popularity, empirical support has been mixed. Grantham [39] argues that assessment has been difficult, limiting its impact on gifted education [5], [40]. Sternberg [7] and Renzulli's [41] work clearly broadened educators' conceptions of what giftedness and talent can be, where or how it can be found. Talent is the demonstrated mastery of the gift as evidenced by skills in academics, arts, business, leisure, sports, or technology that place the individual in the top $10 \%$ of age peers [2]. This study emphasizes the role of socio-cultural context [5] in defining, identifying, and fostering giftedness which correlate with the recent studies like Kaluda [14] and Gubbin [42] that raised the importance of motivation and engagement in resulting higher achievements and success to the gifted programs.

The results of the fifth question indicate that the school principals gave higher ranking to the following types of provisions offered by school to gifted students: Grouping students according to their gifted abilities, doing projects in students' areas of strengths and interests, through enrichment programs that broadly develop students' horizons and interests. This result reiterate Heuser, et al. [35] study that indicated one of the constructs of intelligence and ability is through individualistic versus collective dimension. The participant school principals did not give high attention to other giftedness provisions such as engaging students in problem solving, accelerating programs probably because it is not available in their schools. Quek, et al. [28] in their study imply the importance of customizing instructions, and infusing creative and critical thinking skills through providing gifted students with open-ended questions, challenging and intellectually stimulating programs.

The results of the sixth question generally indicate the homogeneity of the sample, as there were almost no significant differences among them in their perspectives on methods of identifying gifted students. The results have shown that the school principals' perceptions of giftedness very closely knitted with cognitive abilities. It narrowed the concept of giftedness as merely intellectual abilities whereas talent is the demonstrated mastery of the gift as evidenced by skills in arts, business, leisure, sports, or technology that place the individual in the top $10 \%$ of age peers [2]. Little provision in terms of identifying and appreciating giftedness in terms of natural talents, creativity and cultural aspects as reflected in the existing literature [29], [20] which indicated effective school principal need to have a general understanding of the foundations of giftedness and gifted education along with student characteristics, instructional approaches and financing.

Findings from this study reflect existing research [20], [29] that reveals dissonance between what the principals' perceptions on giftedness are and the educational support that they provided to the gifted students in their schools. Contrary to the research done by David [13] which highlighted the need for the administrative institutions to be actively involved in not only the identification process of giftedness but also provide a comprehensive support to the gifted programs. Smedsrud [6] contended that the traditional approach of identifying giftedness have impact on how the educational provisions are made. Limitations notwithstanding, findings from this study provide useful and timely information about Bahrain school leaders' preparation in terms of provisions and support.

First, the matter of equity deemphasized in the discourses [39], [43]. To overcome the dissonance of equity and excellence, the field of gifted education needs to agree on what giftedness means and what the processes of identification and services should be for gifted programs. Also, more inclusive discussions are required in terms of nature versus nurture of giftedness. As the study done in Bahrain [21] actually differentiated gifted to talented students. The provision for its programs will differ accordingly. It is worth to 
point out that students who identified as gifted are not properly served in an equitable manner and culturally responsive way. Plausible explanation to these could be resulting from the understanding of the concept of giftedness. Furthermore, the researchers argue that it could be due to the lack of understanding of the global dimensions of giftedness, and the need for more resources and expertise in schools.

Jones [43, p. 8] argued, "Many identified gifted students are not receiving the needed academic support through a relevant and rigorous curriculum." There is a need to review curriculum, as it is pivotal that stakeholders, like the school leaders, administrators, education ministry, academics and educational researchers, work simultaneously to identify gifted students in a more open and broad perspectives rather than limit to mere cognitive abilities. This will certainly enable the gifted students to receive support in ways that their intellectual capacities are optimally stimulated and nurtured.

In this present era where discussions on education become mired in measurement, processes, and outcomes, Biesta [44] urged for a refocus on the purpose and direction of good educational programming. Ideally, culturally relevant leadership in gifted education should aim to meet the individualized needs of students through challenging and accelerated curriculum [45]. This should occur in a climate that fosters optimal growth and provides ample opportunities for students to home and cultivate their domain specific talents and ultimately inculcate the joy of discovery and learning [2], [46]. School principals should also "identify policies that align with the stated intent and goals of the program in a transparent process that strives for inclusion, not exclusion” [47, p. 75]. A successful gifted program promotes inclusion and requires educational leaders to translate a vision of excellence and equity into reality [48] in a much broader perspective.

Challenges with funding gifted programs due, in part, to a need for more explicit educational policies also have been problematic for nurturing these gifted students [49]. Schools become more inclusive when leaders make decision that disrupt equity [50]. The impetus for creating inclusive and equitable learning environments involves a conscious shift from deficit thinking to strengths-based paradigms at the individual and systemic levels, an emphasis on high expectations for not only academic performance, but also in harnessing other forms of talents and creativity. Educators need to be critically aware to address the need for addressing diversity issues in schools.

Curriculum is significant in identifying and serving gifted students' programs [2]. Differentiating curriculum and instruction are crucial to not only support these gifted and talented students in terms of "responsive to students' points of readiness, interest and learning profile" [4, p. 45] but also to value and embrace multiple cultures in the curriculum content and creating robust teaching and learning processes.

Bahrain Teachers College could start by answering NAGC [51] call to action. As a teacher training college, academics and educational leadership programs could include courses that promote giftedness and inclusion. School principals need motivation to create a school climate that supports excellence. Professional development courses aligned to address the need for gifted education. Teachers training are important on the needs of gifted students from diverse populations, teacher collaboration, and other recommendations focused on curriculum and progress monitoring. Genuine progress in advancing giftedness and gifted education requires academics and practitioners to engage actively in progressive conversation with educators to develop and use socially responsive curriculum that connects to students' real-life experiences and communities that include multiple voices and perspectives.

The researchers would like to propose that the educational system in Bahrain too may need an excellence orientation policy supporting Stephens [36] calls toward different students psychological make up, laudable based on their diverse talents to better meet the educational demand in pursuing excellence, purposeful design and implementation of giftedness programs for administrative institutional leaders [13] to implement the high standards in Bahrain public school.

Research could dig deeper on how the school leaders can adopt differentiation curriculum practices that provide students with deeper understanding [35] of the subject matter that go beyond the ordinary tasks. Education is a unified effort from all stakeholders. Parental involvement is also crucial to ensure progress and success. Khalifa [37] conquers that these partnerships, facilitated by school leaders, between educators and parents can help develop cultural competence, empathy, and communication that support student growth. Gifted education and educational leadership scholars' alike need to agree to Mansfield [52] argument that policies and effective standard practices promoting gifted education are very critical and must never undermine social justice as this would reduce public trust in school leaders.

\section{CONCLUSION}

The school principals looked at giftedness mainly from an academic and school perspective. The results indicate some dissonance between what the principals' perceptions on giftedness are and the educational support that they provided to the gifted students in their schools. 
Research in the field of giftedness require to be free from bias. A significant portion of research should reflect unbiased consideration of identification, processes, and models conducted by developers of models and instruments, under consideration, with few third-party studies and replications. Although keeping advocacy and research separate is admittedly easier said than done, it is not impossible. Additional research is needed to clarify some of the points alluded to by the data. Future researchers might wish to investigate how school leaders can clearly identify the characteristics of giftedness. Findings through individual or group interviews from within the survey respondents, to explore avenues on how to create conducive conditions and firm support from the parents and the community are integral in ensuring continuous success. For gifted programs, a consistent reviewed curriculum is pivotal for success of any gifted education.

There is certainly a need for a paradigm shift on the broad concept of giftedness. Educators and school leaders especially need to put away that longstanding notion that measure students' giftedness with only standardization tests. Examining new paradigms for definition, talent development, and identification in conjunction with proposed curricular and serve interventions would provide policy makers with clear pathways in decision making which is not only necessary but also crucial for Bahrain's continuous efforts towards a world-class education.

\section{REFERENCES}

[1] D. Ford, B. L. Wright, A. Washington, and M. S. Henfield, "Access and Equity Denied: Key Theories for School Psychologists to Consider When Assessing Black and Hispanic Students for Gifted Education," Forum: Research in Practice, vol. 10, no. 3, pp. 265-277, 2016.

[2] C. Horn, "Young scholars: A talent development model for finding and nurturing potential in underserved populations," Gifted Child Today, vol. 38, no. 1, pp. 19-31, 2015.

[3] S. Codrington, "Leadership practices that result in high achievement of African American students in an elementary school setting," Doctoral Dissertation, ProQuest Dissertations, and Theses Global, 2015.

[4] L. Finley, "Implementing a differentiated model of gifted education: Perspectives of elementary Principals and teachers," Doctoral Dissertation, ProQuest Dissertations and Theses Global, 2008.

[5] J. Plucker and C. Callahan, "Research on Giftedness and Gifted Education: Status of the field and Considerations for the future," Exceptional Children, vol. 80, no. 4, pp. 390-406, 2014.

[6] J. Smedsrud, "Explaining the Variations of Definitions in Gifted Education," Studies in Education, vol. 40, no. 1, pp. 79-97, 2020.

[7] R. Sternberg, "The theory of successful intelligence," Rev. General Psychol., vol. 3, no. 4, pp. 292-316, 1999.

[8] J. Renzulli, "Emerging conceptions of giftedness: Building a bridge to the new century," Exceptionality, vol. 10, no. 2, pp. $67-75,2002$

[9] F. Gagné, "Transforming gifts into talents: The DMGT as a developmental theory," High Ability Studies, vol. 15, pp. 119-147, 2004.

[10] K. A. Heller, C. Perleth, and T. K. Lim. "The Munich model of giftedness designed to identify and promote gifted students," In J. R. Sternberg and J. E. Davidson, Eds., Conceptions of giftedness. New York: Cambridge University Press, 2005, pp. 147-171.

[11] F. J. Mönks, "Development of gifted children: The issue of identification and programming," In F. J. Mönks and W. A. M. Peters, Eds., Talent for the future. Proceedings of the ninth world conference on gifted and talented children. Assen: Van Gorcum, 1992, pp. 191-202.

[12] R. Viennet and B. Pont, "Education policy implementation: a literature review and proposed framework," Report of the Organisation for Economic Cooperation and Development, 2017.

[13] H. David, "Gifted Education in the Middle East," In S. Pfeiffer, E. Shaunessy-Dedrick and M. F. Nicpon, Eds., Handbook of Giftedness and Talent. TX: APA Books, 2017.

[14] S. Kaluda and J. Guthrie "Comparing Relations of Motivation, Engagement, and Achievement among Struggling and Advanced Adolescent Readers," Reading and Writing, vol. 28, no. 2, pp.239-269, 2015.

[15] D. Matthews and D. Yun Dai, "Gifted education: changing conceptions, emphases and practice," International Studies in Sociology of Education, vol. 24, no. 4, pp. 335-353, 2014.

[16] T. Cross and L. Coleman, "School-Based Conception of Giftedness," Journal for the Education of the Gifted, vol. 37, no. 1, pp. 94-103, 2014.

[17] J. Plucker and S. Barab, "The importance of contexts in theories of giftedness: Learning to embrace the messy joys of subjectivity," In J. R. Sternberg and J. E. Davidson, Eds., Conceptions of giftedness. New York: Cambridge University Press, 2005, pp. 201-216.

[18] L. Corno and L. J. Cronbach, Remaking the concept of aptitude: Extending the legacy of Richard E. Snow. Mahwah, NJ: Erlbaum, 2002.

[19] R. Snow, "Aptitude theory: Yesterday, today, and tomorrow," Educational Psychologist, vol. 27, no. 1, pp. 5-32, 1992, doi: 10.1207/s15326985ep2701_3.

[20] M. Ezzani and M. Brooks, "Culturally relevant leadership: Advancing critical consciousness in American Muslim students," Educational Administration Quarterly, vol. 55, no. 5, pp. 781-811, 2019. 
[21] N. Sulaiman, F. A. Al-Jasim, and A. M. Abdulla, "Assessing the Emotional Intelligence of Gifted and Talented Adolescent Students in the Kingdom of Bahrain," Roeper Review, vol. 39, no. 2, pp. 132-142, 2017, doi: $10.1080 / 02783193.2017 .1289462$

[22] D. Chan, "Gifted Education in Asia," In S. Pfeiffer, E. Shaunessy-Dedrick and M. F. Nicpon, Eds., Handbook of Giftedness and Talent. TX: APA Books, 2017.

[23] National Association for Gifted Children, "Meeting the needs of high-ability and high-potential learners in the middle grades: A joint position statement of the National Middle School Association and the National Association for Gifted Children," Gifted Child Quarterly, vol. 49, no. 2, pp. 189-190, 2004.

[24] M. Endepohls-Ulpe and H. Ruf, "Primary school teachers' criteria for the identification of gifted pupils," High Ability Studies, vol. 16, no. 2, pp. 219-228, 2006.

[25] T. Moon and C. Brighton, "Primary Teachers' Conceptions of Giftedness," Journal for the Education of the Gifted, vol. 31, no. 4, pp. 447-480, 2008.

[26] S. Laine, et al. "Finnish Teachers' Conceptions of Giftedness," Journal for the Education of the Gifted, vol. 39, no. 2, pp. 151-167, 2016

[27] R. Sternberg and J. Davidson, Conceptions of giftedness, 2nd ed. New York: Cambridge University Press, 2005.

[28] C.L. Quek, A.F.L. Wong, and B. Fraser, "Determinants and effects of perceptions of chemistry classroom learning environments in secondary school gifted education classes in Singapore," AARE Conference, Australia, 2001.

[29] M. DiPaola and C. Walther-Thomas, "Principals and special education: The critical role of school leaders," (COPSSe Document No. IB-7). Gainesville, FL: University of Florida, Center on Personnel Studies in Special Education, 2003.

[30] M. Boscardin, "The administrative role in transforming secondary school to support inclusive evidence-based practices," American Secondary Education, vol. 33, no. 3, pp. 21-32, 2005.

[31] F. Hess and A. Kelly, "The accidental principal: What doesn't get taught at ed schools?" Education Next, vol. 5, no. 3, pp. 34-40, 2005a.

[32] F. Hess and A. Kelly, "The innovative look, a recalcitrant reality: The politics of principal preparation reform," Educational Policy, vol. 19, no. 1, pp.155-180, 2005b.

[33] C. Nagara, "Creative vision and inspiration of Shona Stone Sculptors," Psychology of Aesthetics, Creativity, and the Arts, vol. 4, no. 3, pp. 181-192, 2002.

[34] C. Nagara, and O. Al-Mahdi, "An exploratory study of teachers' perceptions of giftedness and talent among students in Bahraini primary schools," Journal of Teaching and Teacher Education, vol. 4, no. 1, pp. 17-29, 2016.

[35] B. Heuser, et al., "Global dimension of Gifted and Talented Education: The influence of National Perceptions on Policies and Practices," Global Education Review, vol. 4, no. 1, pp. 4-21, 2017.

[36] K, Stephens "Gifted education policy and advocacy: Perspectives for school psychologists," Psychology in the School, vol. 57, no. 10, pp. 1640-1651, 2020.

[37] M. Khalifa, Culturally responsive school leadership. USA: Education Press, 2018.

[38] H. Gardner, Frames of mind: The theory of multiple intelligences. New York, NY: Basic Books, 1983.

[39] T. Grantham, "Eminence-focused gifted education: Concerns about forward movement void of an equity vision," Gifted Child Quarterly, vol. 56, no. 4, pp. 215-220, 2012.

[40] H. Gardner, "Reflections on multiple intelligences: Myths and messages," Phi Delta Kappan, vol. 77, pp. 200-209, 1995.

[41] J. Renzulli and S. D'Souza, "Intelligences outside the normal curve: Co-cognitive factors that contribute to the creation of social capital and leadership skills in young people," In J. A. Plucker and C. M. Callahan, Eds., Critical issues and practices in gifted education: What the research says, 2nd ed. Waco, TX: Prufrock Press, 2014.

[42] E. Gubbins, "Promising Practices for Improving Identification of English learners for Gifted and Talented Programs," Journal for the Education of the Gifted, vol. 43, no. 4, pp. 336-369, 2020

[43] D. Jones, "The relationship between superintendents' beliefs about gifted education and the placement rate of minority students in programs for the gifted," Doctoral Dissertation, ProQuest Dissertations and Theses Global, 2009.

[44] G. Biesta, Beyond Learning: Democratic Education for a Human Future. Boulder: Paradigm Publishers; 2006.

[45] M. Neihart and C. Teo, "Addressing the needs of the gifted in Singapore," Journal for the Education of the Gifted, vol. 36, pp. 290-306, 2013.

[46] S. Rimm, D. Siegle, and G. Davis, Education of the gifted and talented, 7th ed. Pearson, 2018.

[47] S. Obi, F. E. Obiakor, S. L. Obi, T. Banks, S. Warner, and N. Spencer "Giftedness as it relates to culturally and linguistically diverse students," In J. P. Bakken, F. E. Obiakor and A. F. Rotatori, Eds., Gifted education: Current perspectives and issues. Emerald Group Publishing, 2014, pp. 71-100.

[48] L. Johnson and C. Fuller, Culturally responsive leadership. Oxford University Press, 2014.

[49] J. Jolly and J. Robins, "After the Marland Report: Four decades of progress?" Journal for the Education of the Gifted, vol. 39, no. 2, pp. 132-150, 2016.

[50] M. Scanlan and F. López, Leadership for culturally and linguistically responsive schools. Routledge, 2014.

[51] National Association for Gifted Children, "2010 Pre-K to Grade 12 gifted programming standards," nagc.org, 2019. [Online]. Available: https://www.nagc.org/resources-publications/resources/national-standards-gifted-and-talentededucation/pre-k-grade-12.

[52] K. Mansfield, "Giftedness as property: Troubling whiteness, wealth, and gifted education in the United States," International Journal of Multicultural Education, vol. 17, no. 1, pp. 1-18, 2015. 